\title{
ナイジェリア・カドナ地方における花崗岩質風化残積土 の地盤工学的考察
}

\author{
GEOTECHNICAL ENGINEERING STUDY ON DECOMPOSED GRANITE \\ SOILS IN KADUNA DISTRICT, NIGERIA
}

\author{
末 岡徹* ·小山哲**. 佐 藤洋 一*** \\ By Toru SUEOKA, Satoru KOYAMA and Yoichi SATO
}

\begin{abstract}
Engineering classification of residual granitic soil in Kaduna district, Nigeria, is clarified on the bases of geochemical, geomechanical and statistical studies.

Geotechnical properties of each soil layer are investigated by performing analytical procedure of perticle size distribution, porosity, $\mathrm{N}$-value and chemical composition. The degree of weathering of the parent rock which belongs to tropical savanna zone is discussed in this paper comparing with the characteristics of residual soil derived from granite in Japan.
\end{abstract}

\section{1.はじめに}

地球における人口が 45 億人を越え, 西暦 2000 年まで には，60 億人に達しようと予想される現在 ${ }^{11}$, 多くの発 展途上国が存在する熱帯地方は, 政治, 経済の問題ばか

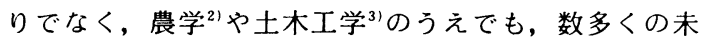
解決な問題が存在する地域であろう. 土木工学の一分野 である土質工学の範ちゅうに限っても，末解決な問題が 数多く存在する.たとえば, 熱帯地方の土の性質は, 必 ずしも, 温帯地方のそれと同一ではなく, 温帯地方で発 達した土質工学の知識や経験が, いつの場合でも, 熱帯 地方において, 適用できるわけではないことが, 明らか にされつつある4),5). しかしながら, 熱帯地方の土の性 質が，どの程度温帯地方のそれと異なるのかという詳し い検討が，十分になされているとはいえず，また，熱帯 地方の土そのものの情報も限られたものしかないという のが実情であろう.

本研究は，熱帯地方の中でも，Köppen の気候区分に よれば，熱帯サバンナ気候（記号 $\mathrm{A}_{\mathrm{w}}$ ）に区分されるナ

* 正会員 大成建設技術研究所地盤研究室 ( 塚区名頛町 344-1)

** 大成建設技術研究所計画室 (同上)

*** 千代田化工建設(株)土木部
イジェリア国・カドナ地方の花崗岩質風化残積土に対し て, 物理的, 化学的, 力学的および統計的な手法を使い, 総合的に考察したものである.すなわち，風化残積土は， 地球表層に存在する岩石の水圈, 大気圈による物理的, 化学的風化作用の結果生成された物質であるという風化 論の見地に立ちながら，カドナ地方の風化残積土に対し， 単に土質工学の範ちゅうによよ゙まらず，広く地盤工学 (Geotechnical Engineering), 地質工学 (Geomechanics）の視点も踏まえて, 検討を加えた. さらに，力ド 十地方の風化残積土之, 日本における花崗岩質風化残積 土であるマサ土との土の物理的, 化学的, 力学的性質を 比較し, 温帯および熱帯地方における花崗岩質風化残積 土の性質の違いを明確化することを試みた。

\section{2. カドナ地方の地形，地質および気象}

カドナ地方は, ナイジェリア国北部, 北緯 $10^{\circ}$, 東経 $8^{\circ}$ 付近に位置し, 図一1に示すように, ニジェール川の 支流であるカドナ川が，地方の中央部を流れ，海抜 600 $\mathrm{m}$ 程度, 地形勾配 1/200 3/200 の緩い準平原地形から なっている，母岩は，先カンブリア期の古い花崗岩から なっており"，図一1に示すように，島状丘 (bornhardt) と呼ばれる花崗岩の岩山が局所的に露出している61,7). 建設地付近の島状丘は, 建設用の骨材原石山として利用 


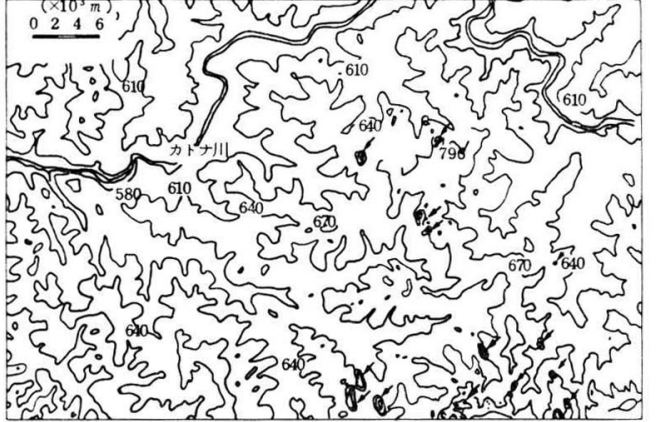

図一1 カドナ地方の地形 (単位: $m$, 矢印は島状丘)

表一1 カドナ地方における地盤の籣易土層区分

\begin{tabular}{|c|c|c|}
\hline 土層 & 深度 $(\mathrm{GL}-\mathrm{m})$ & $\begin{array}{llll}\text { 主 } & \text { な } & \text { 特 } & \text { 徵 } \\
\end{array}$ \\
\hline $\mathrm{A}$ 層 & $0 \sim 0.3$ & 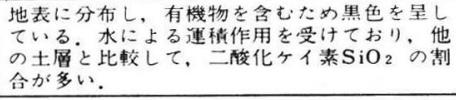 \\
\hline $\mathrm{R}$ 層 & $0 \sim 1$ & 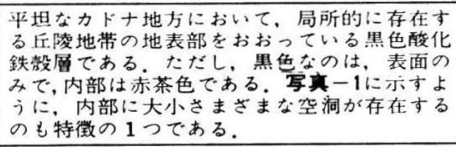 \\
\hline $\mathrm{B}$ 層 & $0.3 \sim 5$ & 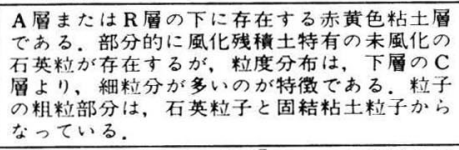 \\
\hline C 層 & $5 \sim 12$ & 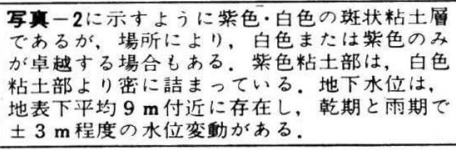 \\
\hline $\mathrm{D}$ 層 & $12 \sim$ 平均 25 & 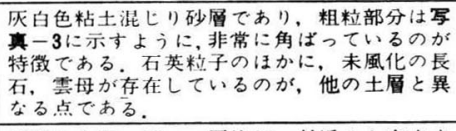 \\
\hline $\mathrm{E}$ 層 & 平均 25 & $\begin{array}{l}\text { 地表から } 20 \sim 40 \mathrm{~m} \text {, 平均 } 25 \mathrm{~m} \text { 付近から存在す } \\
\text { る風化花崗岩首である. }\end{array}$ \\
\hline
\end{tabular}

されることが多い8). 地盤は，先述したように，全般的 には，きわめて平坦であるが，図一2に示すような，高 さ $5 \sim 10 \mathrm{~m}$, 頂部が水平で，その表層が酸化鉄穀層 (hardpanまたは, ferruginous crust) でおおわれた丘 陵が局所的に存在する.この酸化鉄穀層は, 固結してい るため, ラテライト石 (Laterite rock) とも呼ばれ，熱 帯地方では, コンクリート用骨材 ${ }^{9}$ や道路用路盤材 ${ }^{10}$ と して利用されている.この丘陵地形は，風化残積土の旧 地盤面が浸食をまぬがれて残積したものと考えられてい $3^{7), 11)}$.

カドナ地方における代表的土層断面を示すと, 図一2 のようになる. 風化を受けた花崗岩は, 地表下 20 ４0 $\mathrm{m}$ で出現し, 風化前線の形が地表面地形より起伏に富 んでいるのが特徴的である. カドナ地方の代表的土層断 面に対し, 主に土色に基づいて, 簡易土層区分を行うと, 図一2のようになり，各土層の主な特徵を述べると，表

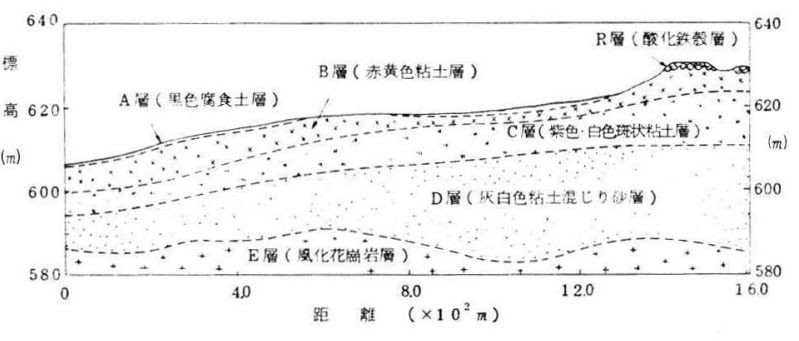

図一2 カドナ地方の典型的な土層断面

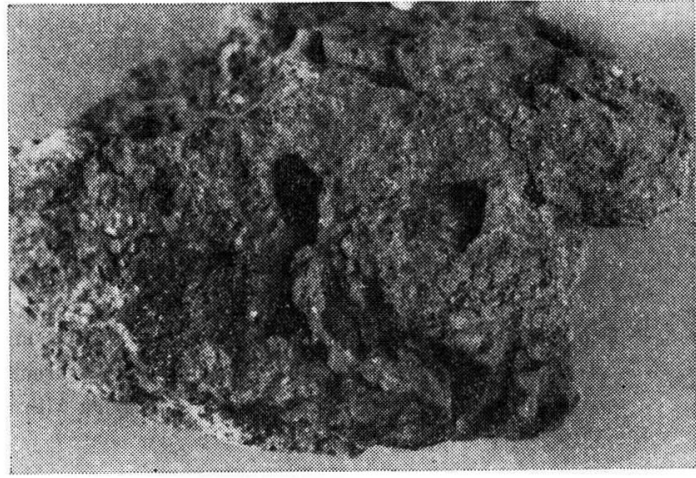

写真一1 酸化鉄款層試料（R層）

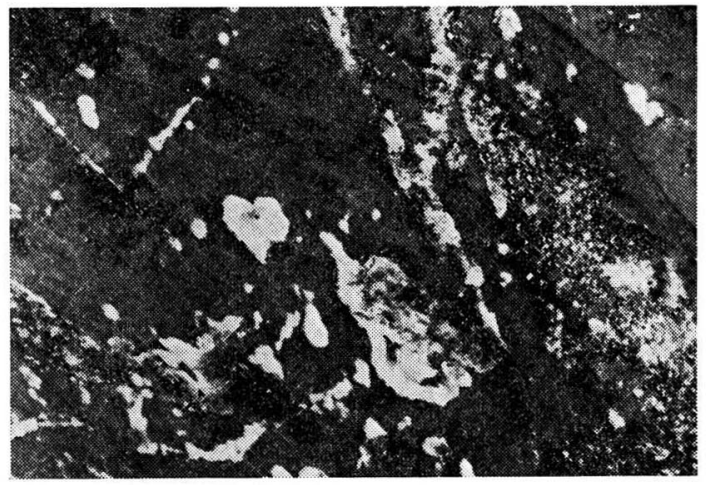

写真一2 紫色・白色斑状粘土層 ( C 層)

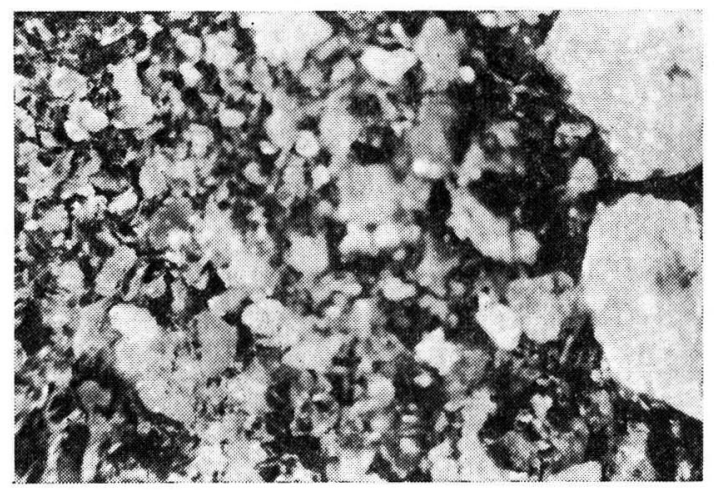

写真-3 D 層試料 $(\mathrm{GL}-15 \mathrm{~m})$ の $74 \mu \mathrm{m}$ 以上の粗粒部分 


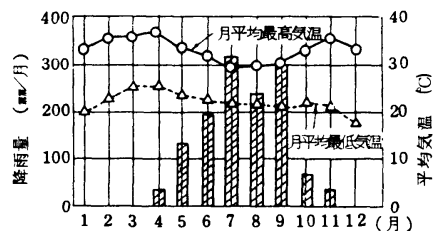

図一3 カドナ地方の気象データ (1979 年)

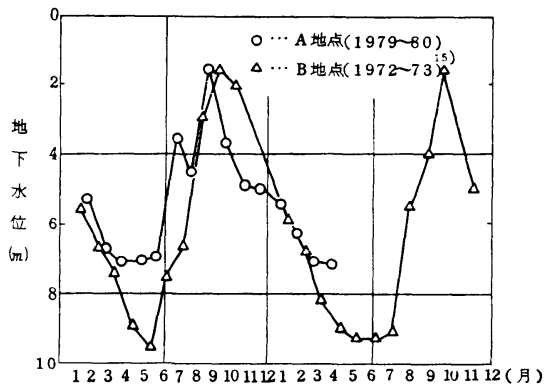

図一4 カドナ地方の井戸における水位の季節变動

-1のようになる．図一2 や表一1は，あくまで簡易土 層区分であり，後の章で詳細な検討を行う.

次にカドナ地方の気象の特徵について述べる以下の ようになる。すなわち，カドナ地方は，図一3に示すよ うに，乾期と雨期の区別が明確なサバンナ気候であり， 年間 $1300 \mathrm{~mm}$ 程度の雨量が 5 月から 10 月までの半年 間に集中する. 1 回の降雨形態は, 温帯地方のそれと異 なり，短期間に集中的に降るのが特徵である。これらの 降雨形態を含めた熱帯サバンナ気候が, 酸化鉄穀層丘陵 や島状丘を局所的にもつが，全般的にはきわめて平坦な カドナ地方全域の地形形成に影響を及ぼしていると考え られる ${ }^{12), 13)}$.

地下水位は，先述したように熱帯サバンナ気候の影響 を受け, 季節変動が著しい. カドナ地方の風化残積土地 盤では, 全般的に, 乾期亡雨期で $\pm 3 \mathrm{~m}$ 以上の地下水 位変動があり，カドナ川支流の中小河川付近の村落井戸 では, 図一4に示すような地下水位の変動が観察される.

カドナ地方は，图一3からもわかるように，半年間ほ とんぞ降雨がなく, 年間日射時間は 2700 時間を越え ${ }^{(4)}$, また, 年間の水分蒸発量は $2500 \mathrm{~mm}$ に達する ${ }^{15}$. すな わち, 年間水分蒸発量が年間降雨量より大きなことも, 温帯地方に位置する日本の気候と異なる点である.

\section{3. 風化残積土の物理化学的性贔}

カドナ地方における花崗岩質風化残積土は, 日本のよ うな温帯地方の風化残積土とかなり土の性質が異なると 思われる. 本章では, 物理的, 化学的手法を使いながら, カドナ地方の風化残積土の特性を検討する。なおボーリ ング, サンプリングは, 乾期である 2 月に, 行っている.
雨期においても，地形が平坦で急傾斜地もなく，また， 地表付近の土質が固い粘性土で構成されていることか ら, 乱さない限り, 乾期と比較して極端に地盤の強度が 低下することはない。調査は, 風化残積土地盤に対し, 約 10 万 $\mathrm{m}^{2} に 1$ か所の割合で行っており, 土質試験結 果は, ほぼ,この地方の平均的な地盤特性を表わしてい ると考えられる。 サンプリングは，中一硬質粘土に対し 英国で, 最も一般的なシンウォールオープンドライブサ ンプラーを使用している，風化残積土であるため，乱れ の影響が心配されたが，力学試験を行う試料が硬い低塑 性の粘性土であること, また, 他の採取方法を取ること がナイジェリアで困難であることを考慮して，やむを得 ず，本サンプリング方法を採用している.

（1）風化に伴う自然含水比および土の飽和度の変化 カドナ地方における風化残積土地盤の自然含水比の変 化を深度ごとに示すと，図一5のようになる．自然含水 比は, 地表下 $8 \sim 10 \mathrm{~m}$ 付近で最大となっており, しか もこの深度付近で, 自然含水比のばらつき度合の 1 つの 指標である標準偏差値も大きな值となっている。，一方， 土の飽和度の変化を調べてみると, 図一6のようになり, 乾期においても, 地表下 $1 \mathrm{~m}$ 以深の地盤では, 飽和度 が $60 \%$ 以上存在することがわかる。なお，図一6にお

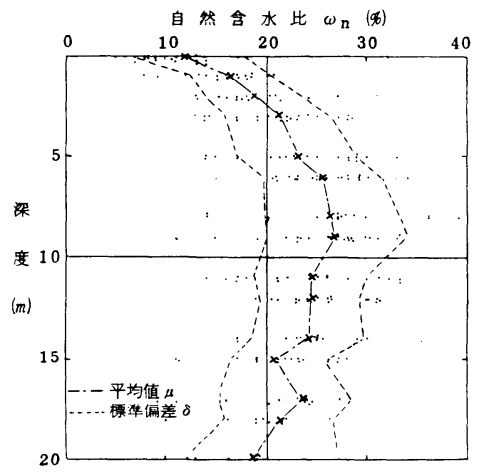

図一 5 自然含水比 $\omega_{n}$ の深度別变化 ( 2 月)

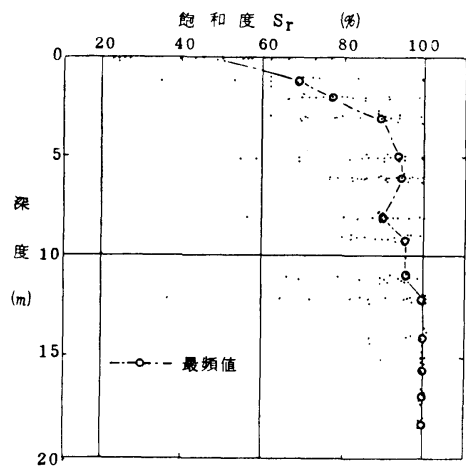

図一6 飽和度 $S_{r}$ の深度別变化 (2 月) 
いて, 土の飽和度の代表値は, 平均值ではなく最頻值を 採用している.

\section{（2）風化に伴う粒度分布の变化}

カドナ地方における風化残積土地盤各土層の代表的粒 度分布を示すと，図一7のようになる，日本における典 型的なマサ土の粒度分布も合わせて図示するが，D層 $(\mathrm{GL}-12 \sim-25 \mathrm{~m})$ 試料の粒度分布が，やや，粘土・ コロイド分が多い傾向はあるが，比較的，マ开土の粒度 分布と似ていることがわかる.

ところで, 締め固めに適した粒度分布の理想型に, Talbot の曲線があるが, Talbotによれば， $P$ を材料の 通過百分率, $d$ を材料の粒径, $D$ を最大粒径, $n$ を指 数之すれば,

$$
P=(d / D)^{n}
$$

が成り立ち, 上式の $n=0.25 \sim 0.50$ の場合が最もよく, 土は締まりやすいといわれている ${ }^{16}$. カドナ地方の風化 残積土においては, B 層, D 層試料は, 比較的 Talbot の曲線に近く，締め固めに適した土質と考えられるが， $\mathrm{C}$ 層試料は, シルト分の割合が多く, 締め固めには, 適さない粒度分布であることがわかる。

風化に伴い, 各土層地盤の粒度構成がざのように変化 しているかを調べてみると，図一8のようになる。一般 に, 風化残積土地盤の場合, 風化の進行に伴い, 粘土・ コロイド分が, 増加し, 粒度は細粒化すると考えられる が, 図一7, 図一8の結果を詳細に調べてみると, 次の

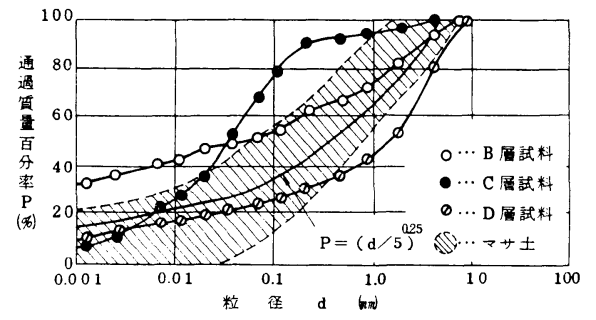

図一7 各土層の代表的粒度分布

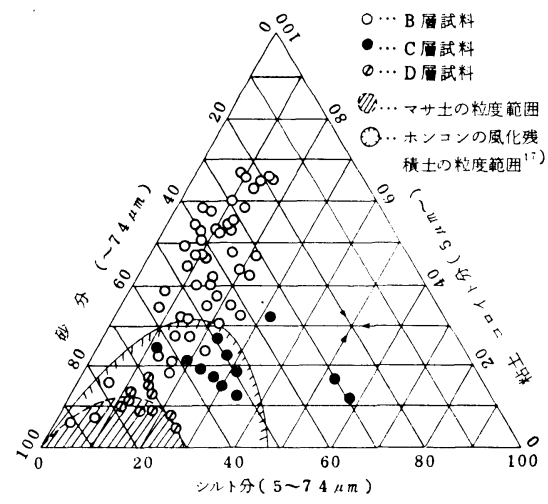

図一8 風化に伴う粒度棬成の変化
ようなことがわかる。すなわち，粒度分布は， D 層 $\rightarrow C$ 層 $\rightarrow \mathrm{B}$ 層と深度が浅くなり, 風化が進行するに従い, 確かに, 粘土・コロイド分は増加し, 粒度は細粒化して いる。しかし，細粒化の割合は一椂ではなく，D層 $\rightarrow C$ 層の層変化では, 砂分が減少し, シルト分が大幅に増加 する傾向が卓越するが， $\mathrm{C}$ 層 $\rightarrow \mathrm{B}$ 層の層変化では， シ ルト分が減少し，粘土・コロイド分が増加する傾向が卓 越している，その結果, $\mathrm{B}$ 層, $\mathrm{D}$ 層試料は, 細粒分か ら粗粒分までバランスのよい粒度構成となっているが, C 層試料はシルト分の割合が多く, バランスの崩れた 粒度構成となっている，表一1で述べたように， B 層試 料の粗粒部分は, 石英粒子のほかに, 土が再固結してで きた粒子を含むことが多く, 風化が進むにもかかわらず， 粗い粒子が増加することは, 非常に興味深い現象である. この現象の極端な例が, 酸化鉄穀層（ $\mathrm{R}$ 層）をもつ丘 陵地盤と考えることができる。 また，図一8からわかる ように，風化が進むに従い，各土層試料の粒度構成のう えで, 砂分, シルト分, 粘土・コロイド分といった各粒 度構成分のばらつき度合が，大きくなってくるようであ る. Lumb ${ }^{17}$ は, ホンコンの花崗岩質風化残積土につい て詳細な研究を行い, 全試料の粒度構成が, 図一8のハッ チで示した範囲に入るとしており，図一7に示す日本の 代表的业土の粒度構成も考慮に入れると，熱帯地方に 近づくに従い，そして，多分，地形勾配が緩くなるほど， 多様な粒度構成となることが推測される。

\section{（3）風化残積土の酸化第二鉄成分が土性に及ぼす影}

熱帯地方の風化残積土は, 激しい風化作用を受け, 相 対的に, 酸化アルミニウム $\mathrm{Al}_{2} \mathrm{O}_{3}$ 成分や酸化第二鉄 $\mathrm{Fe}_{2}$ $\mathrm{O}_{3}$ 成分が増加してくる，本節では，特に，酸化第二鉄 成分が，風化残積土の粒度分布やコンシステンシーにど のような影響を及ぼしているかを調べるため，土壤分析 で行われている Mehra-Jackson 法により，B 層試料の 脱鉄処理を行い, 検討する. 脱鉄処理後の試料は, 処理 の影響で $\mathrm{Na}$ 飽和となっている，脱鉄処理により，B 層 試料の $420 \mu \mathrm{m}$ 以下の粒度分布は, 図一9に示すように 変化し，化学成分は，表一2のように変化している。す

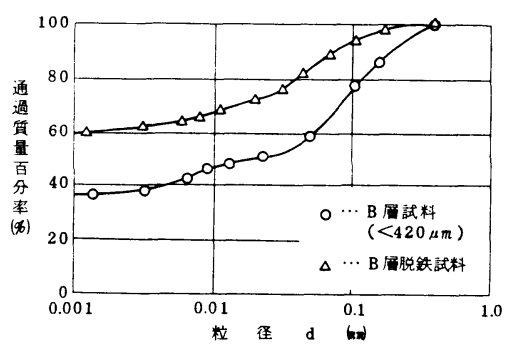

图一9脱鉄処理による粒度変化 


\begin{tabular}{|c|c|c|c|c|c|c|c|c|c|c|c|c|c|c|c|c|}
\hline 試 & G. & $\mathrm{LL}(\%)$ & $\mathrm{PL}(\%)$ & PI & $\begin{array}{l}\mathrm{CEC} \\
\text { meq } 100 \mathrm{~g}\end{array}$ & $\mathrm{SiO}_{2}$ & $\mathrm{Al}_{2} \mathrm{O}_{3}$ & $\mathrm{Fe}_{2} \mathrm{O}_{3}$ & $\mathrm{FeO}$ & $\mathrm{Na}_{2} \mathrm{O}$ & $\mathrm{K}_{2} \mathrm{O}$ & $\mathrm{MgO}$ & $\mathrm{CaO}$ & $\mathrm{MnO}$ & $\mathrm{H}_{2} \mathrm{O}(+)$ & $\mathrm{H}_{2} \mathrm{O}(-)$ \\
\hline $\mathrm{B}-\mathrm{L}(>420 \mu \mathrm{m})$ & - & - & - & - & - & 55.7 & 20.8 & 10.1 & 0.38 & 0.99 & 1.60 & 0.08 & 0.004 & 0.13 & 7.45 & 1.48 \\
\hline $\mathrm{B}-\mathrm{S}(<420 \mu \mathrm{m})$ & 2,798 & 48.2 & 20.7 & 27.5 & 14.2 & 57.5 & 20.2 & 8.97 & 0.41 & 0.98 & 1.44 & 0.11 & 0.01 & 0.09 & 9.34 & 0.93 \\
\hline $\mathrm{B}-\mathrm{SD}$ (脱鉄) & 2,697 & 37.9 & 12.1 & 25.8 & 10.2 & 55.1 & 18.4 & 1.37 & 2.46 & 1.11 & 1.68 & 0.08 & 0.003 & 0.01 & 6.59 & 3.57 \\
\hline C 首 (紫色部) & 2,736 & N.P & N.P & N.P & 7.06 & 56.6 & 21.9 & 9.84 & 0.25 & 1.04 & 0.36 & 0.031 & 0.02 & 0.005 & 6.11 & 0.47 \\
\hline 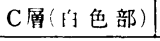 & 2,632 & 53.6 & 34.5 & 19.1 & 4.67 & 66.1 & 23.5 & 0.74 & 0.14 & 0.79 & 0.33 & 0.019 & 0.008 & 0.008 & 6.04 & 2.70 \\
\hline
\end{tabular}

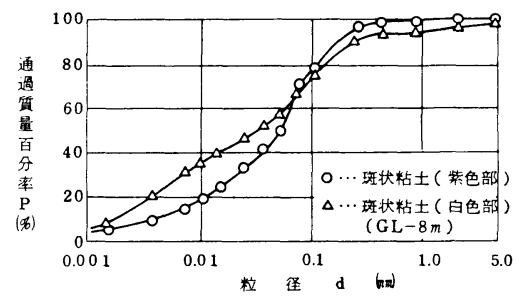

图一10 C 首斑状粘土の粒度分布の違い

なわち，図一9からわかるように，酸化第二鉄 $\mathrm{Fe}_{2} \mathrm{O}_{3}$ 成 分は，粒度分布を見かけ上，粗いものとしており，土粒 子を団粒化させる作用があることが推測される.

一方, 表一2 の化学分析結果に上れば， B 層試料の酸 化第一鉄 $\mathrm{Fe}_{2} \mathrm{O}_{3}$ 成分は, $420 \mu \mathrm{m}$ 以上の粗粒部分に, 上 り多く含まれている. また, $\mathrm{H}_{2} \mathrm{O}(+)+\mathrm{H}_{2} \mathrm{O}(-)$ の值(こ の值は、ほぼ強熱减量の値と同等であり, $\mathrm{H}_{2} \mathrm{O}(+)$ は 粘土鉱物の層間水, $\mathrm{H}_{2} \mathrm{O}(-)$ は, 粘土鉱物の結晶水に 相当すると考えられる $\left.{ }^{181}\right)$ が $9 \%$ 前後存在することか ら, B 層試料の $420 \mu \mathrm{m}$ 以上の粗粒部分には, 表一1で 述べたように，酸化第二鉄 $\mathrm{Fe}_{2} \mathrm{O}_{3}$ 成分の多い粘土が再 固結してできた粗粒子がかなり含まれていることを裏付 けている.

ところで，カドナ地方の風化残積土において，C層 (GL $-5 \mathrm{~m} \sim-12 \mathrm{~m})$ 地盤は，紫色・白色斑状粘土で ある場合が多いことは，表一1で述べたとおりであるが， この玟状粘土の白色部試料と紫色部試料を比較すると, 粒度分布は, 図一10, 化学成分等は表一2のとおりとな る. 化学成分や比重の違いから, C 層の白色部, 紫色 部の違いは, 酸化第二鉄 $\mathrm{Fe}_{2} \mathrm{O}_{3}$ 成分の有無が原因であ ることがわかる．粒度分布は，図一10より，74 $\mu \mathrm{m}$ 以 下の細粒分側で, 白色部試料が紫色部試料より, 細粒分 が卓越していることがわかる。すすなわち，C層斑状粘 土において, 酸化第二鉄 $\mathrm{Fe}_{2} \mathrm{O}_{3}$ 成分の有無による粒度 分布の差異の傾向は, 脱鉄処理による $\mathrm{B}$ 層試料の粒度 分布の差異の傾向之同じであり, カドナ地方の $\mathrm{C}$ 層地 盤では，地盤内において，脱鉄処理と同椂な作用を受け ていると推測される.

一方, 脱鉄処理により，土のコンシステンシーは，表 -2のように変化する．脱鉄処理を行うことにより，液

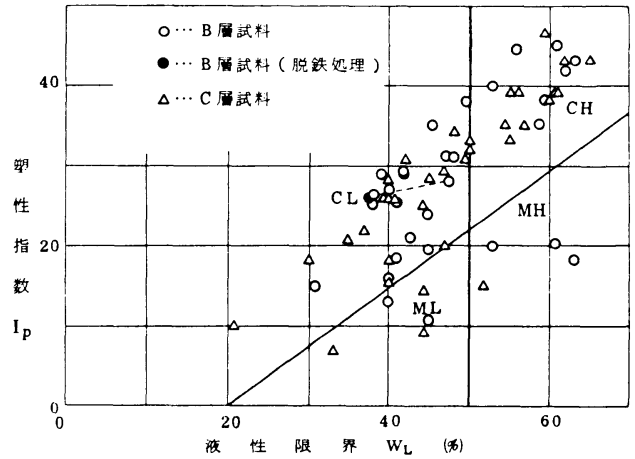

図一11 カドナ地方 B 首，C 首試料のコンシステンシー

性限界，塑性限界とも減少している。酸化第二鉄 $\mathrm{Fe}_{2} \mathrm{O}_{3}$ 成分の多いB 層試料を脱鉄処理することにより，粒度 分布が，図一9に示すように細粒化していることを考慮 すると一見，不合理な結果と考えられる．この原因は， 酸化第二鉄 $\mathrm{Fe}_{2} \mathrm{O}_{3}$ 成分が，粒度試験の際には，土粒子 を団粒化させ，粒度分布を粗いものとする一方，液性限 界, 塑性限界試験の際には，おのおのの限界を増大させ る，すなわち保水能力を增加させる役割を果たしている ためと考えられる。すなわち，粘土鈗物が主にカオリナ イトである B 層試料"の場合, 脱鉄処理により, $\mathrm{Na}$ 飽 和試料となっており，七の保水能力が低下すると考えら れる. 実際, Lambe ら ${ }^{191}$ は，粘土鉱物がカオリナイト で $\mathrm{Na}$ 飽和している場合, 液性, 塑性限界は, 他の陽 オンで飽和している場合より低下することを指摘してい る.しかし，この現象は，粘土鉱物がカオリナイトの場 合に限られ，バーミュキュライトやモンモリロナイトが 主粘土鉱物である風化残積土においては，脱鉄処理に よって $\mathrm{Na}$ 飽和となる場合, 粒度分布も細粒化し, 液性・ 塑性限界も增加する結果が得られている201.

カドナ地方の $\mathrm{C}$ 層試料では, N.P. と判定されるも のもあるが, B 層, C 層試料の塑性図上の位置を示すと, 図一11のようになる，B 層，C 層試料とも，統一分類 に従えば，ML， MH， CH，CL の範用に入るが， $\mathrm{CH}$, CL に区分されるものが比較的多いようである.

\section{（4）風化に伴う土の乾燥密度や間隚事の变化}

カドナ地方における花崗岩質風化残積土地盤におい 
て, 風化の進行度合が土の乾燥密度や間隙率によ゙のよう な影響を及ぼしており，また，日本におけるマサ土地盤 とどの程度性質が異なるかを検討してみる。

カドナ地方の風化残積土地盤における乾燥密度の深度 別変化を調べてみると, 図一12のようになる. 土の乾 燥密度は, 地表下 $8 \mathrm{~m}$ 付近の $\mathrm{C}$ 層で最低值を示してお り，日本におけるマサ土地盤と傾向が異なる．すなわち， マ井土地盤においては, 地表付近まで単調に土の乾燥密 度が減少することが多く211,221，力ドナ地方の場合のよう に，地表付近地盤で土の乾燥密度が明確に増加する傾向 はみられない。また, 乾燥密度のばらつき度合を示す指 標である変動係数 $V$ の值は, 図からわかるように, 地 表下 $10 \mathrm{~m}$ 以浅では, $V \fallingdotseq 0.1$ であるのに対し, 地表下 $12 \mathrm{~m}$ 以深では, ほぼ $V=0.05 \sim 0.07$ となっており, 上 層地盤 (これ以後, 地表下 $12 \mathrm{~m}$ 末満を上層地盤, $12 \mathrm{~m}$ 以深を下層地盤と呼ぶことにする）の方が, 土の乾燥密 度のばらつき度合が大きいことがわかる。ばらつき度合 の変化点は，地表下 10 - $12 \mathrm{~m}$ 付近であり，2. の表一1 で述べたように, 平均的な地下水位低下面とほぼ一致し ていることは, 非常に興味深い.

マサ土の風化度を示す指標に，土の間隙率を用いるこ とが多いが211,221, カドナ地方の風化残積土に対し, 深度

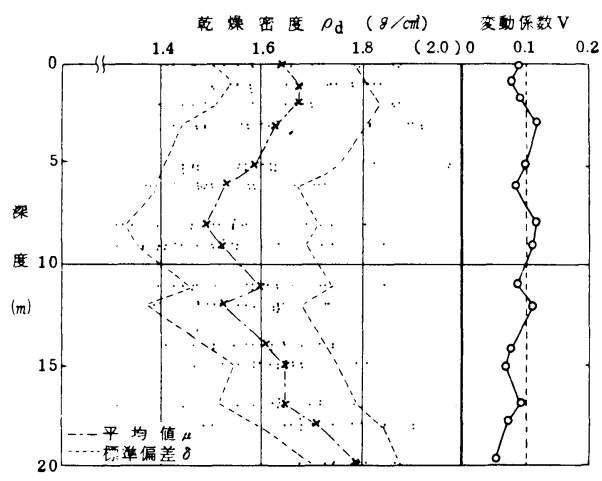

図一12 土の乾燥密度 $\rho_{d}$ の深度別变化

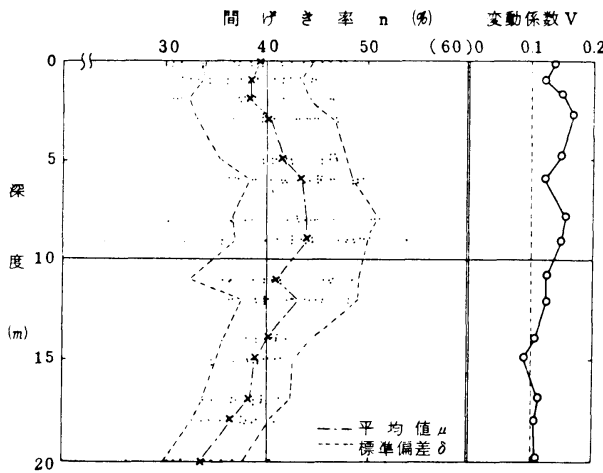

図一13 土の間淨率 $n$ の深度別变化
ごとの土の間隙率の変化を調べてみると, 図一13のよ うになる，土の乾燥密度の傾向から当然であるが，間隙 率も, 地表下 $8 \mathrm{~m}$ 付近で最大值を示しており, また, 間隙率のばらつき度合の指標である標準偏差 $\sigma$ や変動 係数 $V$ の值も, 上層地盤と下層地盤では, 傾向が異なっ ている。すなわち，上層地盤では， $\sigma=0.05 \sim 0.07, V$ $=0.12 \sim 0.18$ であるのに対し，下層地盤では， $\sigma=0.03$ 〜 0.04, $V=0.09 \sim 0.12$ となっている. 表一1や（1） で述べたように，上層地盤は不飽和状態，下層地盤は飽 和状態であることから，飽和地盤と不飽和地盤で間隙率 のばらつき度合が異なることがわかる。

ところで，日本の粘土質マサと呼ばれるかなり風化の 進んだマサ土では, 間隙率が $60 \%$ にも達するものもあ $3^{211.222}$ が, 力ドナ地方の場合, 風化は日本の粘土質マ茾 より進んでいると考えられるB層試料でも，間隙率は $40 \%$ 台であり，一般にカドナ地方の風化残積土の方が, 密に締まった地盤であるといえる.

（5）風化に伴う強熱滅量の変化

日本におけるマサ土地盤の風化度合を示す指標の1つ に, 強熱減量があるが, 強熱減量試験は, 実験施設の少 ない熱帯地方でも簡単に行える試験法である. カドナ地 方における風化残積土地盤の強熱減量值を, 深度ごとに 調べてみると，図一14のようになる，日本における典 型的マ开土地盤の例として, 鳥取市布勢地区のデー夕も 合わせて図示する. 力ドナ地方試料の方が，全般的に強 熱減量の值が大きく, 風化が進んでいるのは, 明らかで ある. 力ドナ地方における地表下 $15 \mathrm{~m}$ 試料 ( D 層) の 強熱減量値 $6 \%$ は, 布勢地区試料の最も風化の進んだ 地盤上層の值よりやや多い程度であり, 風化度もやや進 んだ程度と考えることができよう。小野寺ら ${ }^{221}$ は, 日本 のマサ土において, 図一15に示すような強熱減量と土 の間隙率の関係を得ているが, 熱帯サバンナ気候である カドナ地方の場合も合わせて図示すると,両者の傾向は,

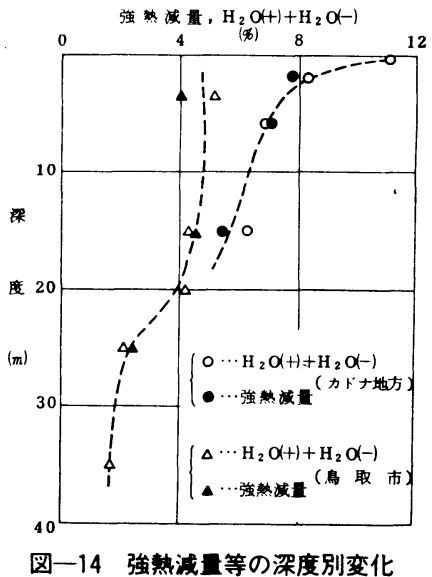




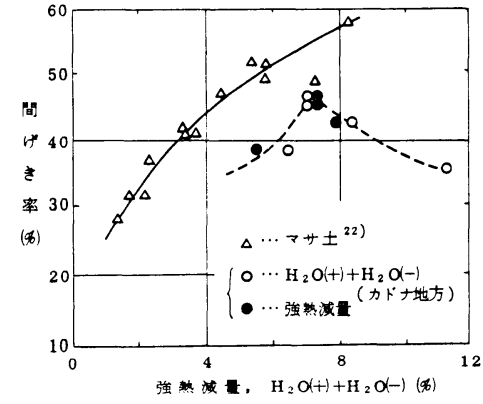

図一15 土の間隙率と強熱減量等の関係

かなり異なっていることがわかる，すなわち，マサ土の 場合，強熱減量の值は，土の間隙率の増加とともに，単 調に増加しているが，力ドナ地方の場合，間隙率は，地 表下 $8 \mathrm{~m}$ 付近の C 層地盤で最大值を示し，この深度以 浅では, 間陌率は, 減少するが, 強熱減量は, 増加して いる.そして, 最終的な風化生成物として, 強熱減量 11 13\%, 間隙率 25３5％の丘陵地带酸化鉄穀層とな るのであろう. 間陌率之強熱減量の関係が, マ开土の場 合と異なるのは, 地表下 $0 \sim 8 \mathrm{~m}$ 付近の地盤において, 風化が進み, 強熱減量は増加するが, 三二酸化物の相対 的集積に加え, 乾期, 雨期の繰り返しにより,地盤が収縮, 再固結化し, 間隙率のみ減少しているためと考えられる.

\section{4. 風化残積土の力学的性質}

前章で述べたように，カドナ地方における風化残積土 は，日本のような温帯地方における風化残積土とかなり 性質が異なる，本章では，原位置における標準貫入試験 や室内における三軸圧縮試験から，カドナ地方における 花崗岩質風化残積土地盤の力学特性について検討する.

\section{（1）風化に伴う $N$ 值の変化}

カドナ地方の風化残積土地盤における標準貫入試験結 果 $(N$ 値) を示すと図一16のようになる. $N$ 值は, 間 隙率の最大值をとるC 層で 20 以下になる部分があるが,

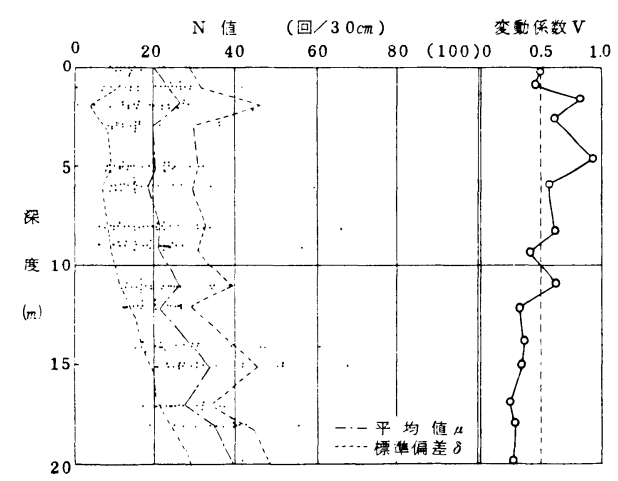

図-16 標辇貝入試験值 ( $N$ 值) の深度变化
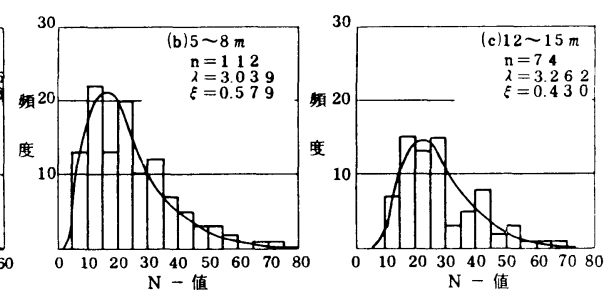

図一17 標準基入試験（ $\boldsymbol{N}$ 值）の深度別頻度

これ以深では, 深度の増加とともに, 増加していること がわかる．日本におけるマサ土地盤の $N$ 值は, 深度の 増加とともに, 単純增加している場合が多く231, カドナ 地方の場合のように, 地盤内で最小値をとることはない。 $N$ 値のばらつき度合を調べてみると，図一16に示すよ うに, 地表下 $12 \mathrm{~m}$ 末満の上層地盤では, $N$ 値の変動係 数 $V$ が, $V \geqq 0.5$ とばらつき度合が非常に大きいのに 対し, 地表下 $12 \mathrm{~m}$ 以深の下層地盤では, $V=0.25 \sim$ 0.35 となっている.すなわち, 乾燥密度や間隙率と同 様の傾向であるが，さらに明確に上層地盤のばらつき度 合が下層地盤より大きいことがわかる.

$\mathrm{B}$ 層, $\mathrm{C}$ 層, $\mathrm{D}$ 層の各土層グループにおける $N$ 值は, どのように分布しているかを調べるため，地表下 $0.3 〜$ $3 \mathrm{~m}$ ( B 層), 地表下 5 8 $\mathrm{m}$ ( C 層), 地表下 $12 \sim 15 \mathrm{~m}$ ( D 層)の 3 土層グループに分け, $N$ 值分布を調べてみると, 図一17のようになる．各グループの $N$ 值分布は有意水 準 $5 \%$ で， $\chi^{2}$ 検定を行うと，(a) グループ以外，対数 正規分布でモデル化できる．Lumbは，ホンコンの花崗 岩質風化残積土地盤において, 粘着力 $c$ や摩擦角 $\phi$ の 分布が，正規分布よりむしろ，ベー夕分布に近いことを 指摘している ${ }^{24}$ が，これらの結果より，乾期を有する熱 帯, 严熱帯地方における風化残積土の強度定数分布は, 正規分布ではなく、ひずんだ分布形となることが予想さ れる．この原因は，3（５）で述べた地盤の収縮，再固結 化が，均質にではなく，不均質に発生しているためと考 えられる.なお, 図で, $\lambda=E(\ln N), \xi=\sqrt{\operatorname{Var}(\ln N)}$ あり, おのおの, 対数 $N$ 值の平均値, 標準偏差を表わ している.

\section{（2）風化に伴う三軸圧縮試験值の变化}

飽和度 $S_{r}=70 \sim 90 \%$ の風化残積土に対し, 側圧 49 $\sim 147 \mathrm{kN} / \mathrm{m}^{2}$, 非圧密非排水状態での三軸圧縮試験 (UU 試験) の結果を深度ごとに示すと図一18のよう になる，粘着力の值 $c_{u}$ は, 深度が浅くなり, 風化が進 むほど, 増加しており, 摩擦角の値 $\phi_{u}$ は, 地表下 $9 \mathrm{~m}$ 付近で最低值を示している.

粘着力の値 $c_{u}$ や摩擦角の值 $\phi_{u}$ がどのような土質係 数と相関があるかを調べるため, 各土質係数間の相関係 数を求めてみると, 表一3のとおりとなる。飽和度 $S_{r}$ $=70 \sim 90 \%$ の範囲であるが, 粘着力 $c_{u}$ は, 飽和度 $S_{r}$, 
表一3 粘着力 $c_{u}$, 摩摖角 $\phi_{u}$ と土質諸係数との相関係数 $(\gamma)$

\begin{tabular}{|c|c|c|c|c|c|c|c|c|c|c|}
\hline & $\begin{array}{c}\text { 飽 和 度 } \\
S_{\text {r }}\end{array}$ & $\begin{array}{c}\text { 含 水 比 } \\
\omega_{n}\end{array}$ & $\begin{array}{c}\text { 乾燥密度 } \\
\rho_{d}\end{array}$ & $\begin{array}{c}\text { 液性限界 } \\
\text { LL }\end{array}$ & $\begin{array}{c}\text { 蜪性限界 } \\
\text { PL }\end{array}$ & $\begin{array}{c}\text { 一軸強度 } \\
q_{u} \\
\end{array}$ & $\begin{array}{c}\text { 粘着打 } \\
\text { cu } \\
\end{array}$ & $\begin{array}{c}\text { 摩擦角 } \\
\phi_{u}\end{array}$ & $<74 \mu \mathrm{m}$ & $\begin{array}{c}\text { 間 陪㳯 } \\
n\end{array}$ \\
\hline 粘着力 $c_{u}$ & 0.291 & -0.254 & 0.645 & -0.376 & -0.263 & 0.737 & - & -0.065 & 0.074 & -0.710 \\
\hline 摩擦角 $\phi_{u}$ & -0.237 & -0.511 & 0.524 & -0.212 & -0.002 & 0.247 & -0.065 & - & 0.351 & -0.475 \\
\hline
\end{tabular}

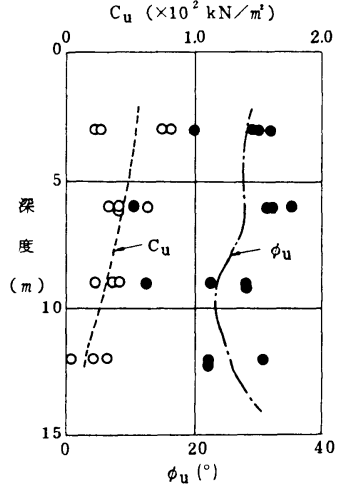

図-18 $c_{u}, \phi_{u}$ 値の深度別变化

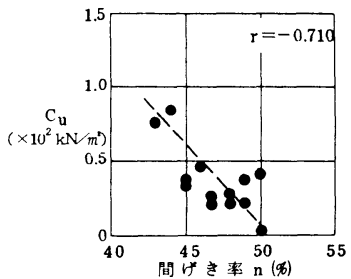

図一19 粘着力 $c_{u}$ と間隙率 $n$ の相関

自然含水比 $w_{n}$, 摩擦角 $\phi_{u}$, 細粒分含有率 $(<74 \mu \mathrm{m})$ とほとんど相関がなく, 乾燥密度 $\rho_{d}$, 間隙率 $n$, 一軸 圧縮強度 $q_{u}$ とかなり強い相関があることがわかる。一 方, 摩擦角 $\phi_{u}$ は, 自然含水比 $w_{n}$, 乾燥密度 $\rho_{d}$, 間隙 率 $n$ と弱い相関をもっている。 一般に, 締め固めた不 飽和土においては, 粘着力 $c_{u}$ 上土の乾燥密度 $\rho_{d}$, ひい ては間隙率とは，相関がないことが報告されている25!。 カドナ地方の乱さない風化残積土の場合，図一19に示 すように, 粘着力 $c_{u}$ と間隙率 $n$ は, かなり相関が強い. この理由は，1つには，試験の側圧が低いため，他は， 乾期, 雨期の繰り返しを有する熱帯サバンナ気候による 風化作用で，土の収縮を伴う地盤の再固結化が発達して いるためと考えられる.

\section{5. カドナ地方における風化残種土地盤の特徵 と工学的土層区分}

風化残積土は，沖積土や洪積土のような運積土と異な り，水による粒子選択や運搬作用を受けていないため， 土層区分が明確でない，しかし，実際の土構造物，構築 物の設計や施工においては，どうしても，風化残積土の
工学的土層区分が必要になってくる，たとえば，盛士の 品質管理の際, 盛土材料の粒度や含水比, 土量変化率の ための乾燥密度，およびそれらの值のばらつき度合が必 要になってくるし，また，深度の異なる多くのフーチン グ基礎の設計には，土層ごとの $N$ 值やそのばらつき度 合を知ることが非常に重要になってくる. 花崗岩質風化 残積土および風化花崗岩の地層区分に対しては，これま で種々の方法が提案されている，たとえば，Ruxtonと Berry ${ }^{26)}$ ，Little ${ }^{27)} ら は$, 風化岩および風化残積土の風 化度に対し，主に地質的特徵からの地層区分を提案して いるし, Scott ${ }^{28)} ゃ L^{2 u m b}{ }^{171}$ らは, 岩石を構成している 一次鉱物や風化によって生成した二次鉱物に注目して, 風化度を判定しょうとしている。 また, Reiche ${ }^{29}$, $\operatorname{Ruxton}^{301}$, 三浦 ${ }^{31}$ らは, 風化岩や風化残積土の化学組成 の変化から風化傾向や風化度を定量化しようとしている し, 風化岩の引張り強度から風化度を定量化しょうとす る研究 ${ }^{32}$ も行われている.

本研究においては，すでに2. で，土色観察による簡 易土層区分を行ったが, 本章では, 前章までの種々の検 討成果を十分活用して, 単に土色ばかりではなく, 定量 的裏付けのある工学的土層区分を行う。すなわち, 強熱 減量, 間隙率, 粒度分布, 自然含水比といった簡便に試 験の行える風化度判定手段のほかに, $N$ 值, $\phi_{u}$ 値, 飽和・ 不飽和の違い, 土質諸定数のばらつき度合の違い, 粒度 構成等を考慮に入れて, 土層区分を行う。ただし, 本研 究においては, 実際の設計や施工の必要性から, 主に風 化残積土層のみの土層区分とし, 風化母岩層の詳しい地 質区分は行わない. また， A 層は，表一1で述べたように， 明らかに, 運積土の特徴を有しており，今回の土層区分 からは除くことにする。

カドナ地方における花崗岩質風化残積土地盤の土性変 化および工学的土層区分を示すと，図一20のようにな る. 2. で行った土色による簡易土層区分は，カドナ地 方の場合，結果的にはほぼ妥当な区分であることがわか るが，表一1でも述べたように，土色は，特にC 層で， 紫色，白色粘土の場所によるばらつきが大きく，土色だ けで土層区分を行うのは，適切でないと考えられる.

最後に，カドナ地方における風化残積土地盤の風化特 性や工学的諸性質についてまとめると次のようになる。

（1） カドナ地方は, 熱帯サバンナ気候の影響を受け， 全般的に地形勾配 1/200～3/300 の非常に平坦な準平原 


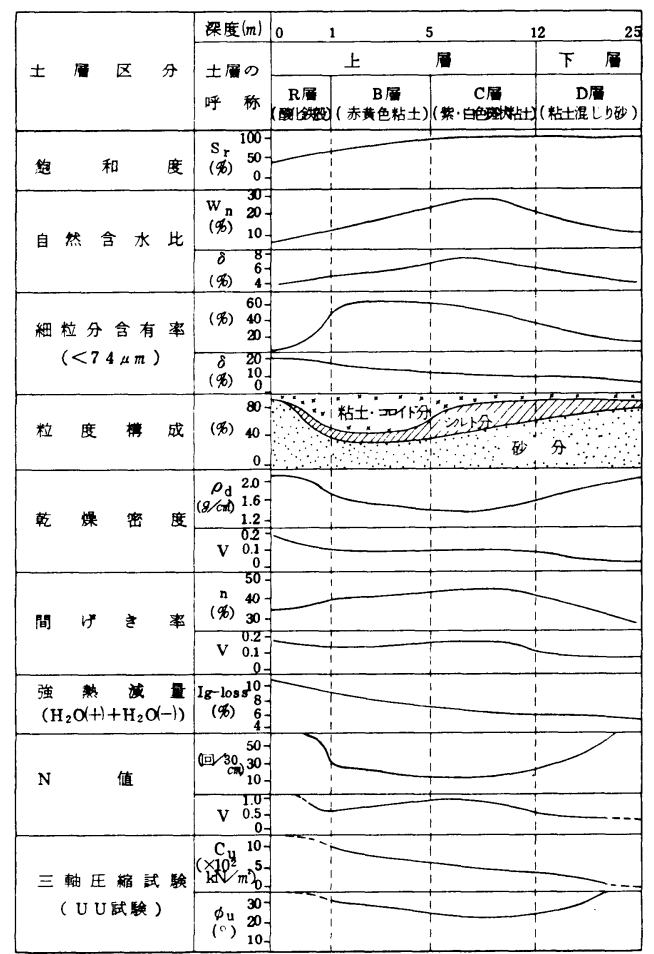

図一20 風化残䅡土の地盤特性と工学的土屋区分

地形からなっており，局所的に島状丘や酸化鉄穀層のあ る丘陵が存在する。

（2）カドナ地方の花崗岩質風化残積土地盤では，明 確な乾期, 雨期を有する熱帯サバンナ気候の影響により, 地下水位が季節的に変動する. 地下水位は, 地表下平均 $9 \mathrm{~m}$ 付近に存在し, 季節により, $\pm 3 \mathrm{~m}$ 以上の水位変 動がある.このため, 地表下 $12 \mathrm{~m}$ 末満の上層地盤では, 不飽和状態であることが多いが，12 $\mathrm{m}$ 以深の下層地盤 では，常に飽和状態である。

（3） B 層, D 層試料の粒度分布は, Talbot の曲線 に近い粒度分布となっているが，C 層試料の粒度分布 は, シルト分含有量が多く, 締め固めには適さない粒度 分布である.また, 各土層の粒度構成は, 深度が浅くなり, 風化が進むほど, 図一8に示すように, 多様なものになっ ている.

（4）三二酸化物の多いカドナ地方のB層地盤におい て，酸化第二鉄 $\mathrm{Fe}_{2} \mathrm{O}_{3}$ 成分は，土を団粒化させる働き があり，見かけの粒度分布を粗いものとしている一方， 土の保水能力を高める働きもしている.

（5）C層地盤の紫色・白色斑状粘土の土色の違い は，酸化第二鉄成分の有無が原因であり，自然界におい ても，人工的な脱鉄処理と同様な作用が働いている.

（6）C 層地盤の地表下 $8 \sim 10 \mathrm{~m}$ 付近において, 自 然含水比, 間隙率は最大值をもち, 乾燥密度, $N$ 値,
摩擦角 $\phi_{u}$ は最小値をもつ.この原因として，地表下 8 $\mathrm{m}$ より浅い三二酸化物の多い地盤において, 乾期, 雨 期の繰り返しによる土の収縮, 再固結化が考えられる. 日本における花崗岩質風化残積土であるマサ土では, 深 度とともに，土質諸係数が単調に変化する場合が多く， カドナ地方の場合のように, 土層内部で, 土質諸係数が 明確な最大值や最小値をもつことはない。

（7）上層地盤における $74 \mu \mathrm{m}$ 以下の細粒分含有率, 間隙率， $N$ 值等の土質試験値のばらつき度合は，下層 地盤より大きく，これらの試験值のばらつき度合の変化 が, カドナ地方の風化残積土地盤の工学的土層区分の目 安になる。

（８）風化度判定手法として強熱減量試験は, 実験施 設の少ない熱帯地方においても簡単に行える試験であ る. カドナ地方における強熱減量の值は, 地表付近ほよ゙ 大きな値となっており, 風化が, 地表に向かって進行し ていることを裏付けている.

（9） カドナ地方における地表下 $15 \mathrm{~m}$ の D 層試料の 風化度は, 強熱減量や粒度分布から判断すると, 鳥取市 布勢地区の地盤最上層マサ土より若干進んでいる程度で あり，カドナ地方地盤の方が全般的に風化が進んでいる.

（10）同一深度グループにおける $N$ 值の分布は, 正 規分布ではなく，対数正規分布で近似できる．この原因 は，地盤が不均質に再固結しているためと考えられる．

（11）非圧密非排水三軸試験による粘着力 $c_{u}$ は, 地 表付近に近づき，風化が進むほど，大きな値となり，土 の間隙率と相関をもつ.

\section{6. あとがき}

以上,ナイジェリア・カドナ地方における風化残積土 の地盤特性, 工学的性質や土層区分, 日本のマ开土との 相違点について検討した．本文をまとめるにあたり，ナ イジェリア国・ベニン大学土木工学部長 S. A. Ola 教授 には，種々の土質試験で助力をいただいた，大成建設技 術研究所 金子誠二, 安 伸二, 村松正重, 深沢道子の 諸氏には，各専門分野からの助言をいただいた。また， 京都大学防災研究所 柴田 徹教授, 九州大学工学部 山 内豊聡教授, 関西大学工学部 西田一彦教授, 埼玉大学 工学部 小田匡寛助教授, 大成建設技術研究所 中尾健児 室長には，常日頃からご教示や激励のことばをいただい ている.ここに合わせて深く謝意を表する.

\section{参 考 文 献}

1）アメリ力合臯国政府特別調查報告（逸見謙三・立花一雄 監訳)：西暦 2000 年の地球 (Global 2000 Report to The President), 家の光協会刊, 環境編, pp. 11, 1981 年 2 月.

2) 北村ほか：熱帯農業のあり方を探る, 農業土木学会誌, Vol. 51, No. 1, pp. $57 \sim 66,1983$ 年 1 月. 
3）室田ほか：比較河川学, 土木学会誌増刊号, pp. 7 12, 1983 年 4 月.

4）高田・門田・末岡：熱帯風化残積土の土質工学的特性之 路盤材としての利用, 土と基礎, Vol.29, No.12, pp. 27 $\sim 32,1981$ 年 12 月.

5）平野 実：地域別に見る世界の土質関係規準とその運用 ーアフリカ, 土と基礎, Vol. 30, No. 6, pp. 30 35, 1982 年 6 月.

6) Ollier, C.D. (松尾新一郎 監訳)：風化一その理論と実 態,ラティス刊, pp. 282, 1971 年 12 月.

7) F. マハチェク著, H. クラウェル，C. ラチェンス改訂 (松 尾新一郎 監訳)：地形学, ラティス刊, pp. 122 123, 1976 年.

8）高田・末岡・坂上：ナイジェリアの生活とコンクリート, コンクリート工学, Vol. 19, No. 1, pp. 63〜 66, 1981 年 1 月.

9) Kenze, W., Koblenz, F. and Brodda, R. : Zur eignung von laterit als betozuschalag, Betonwerk Fetigteil Technik (DEU), pp. 559 561, 1976.

10) De Graft-Johnson : Laterite soils in road construction, 6th Reg. Conf. of Africa on S. M. F.E, pp. $89 \sim 98$, 1975.

11) Gidigasu, M. D. : Mode of formation and geotechnical Characteristics of Ghana in relation to soil forming factors, Engineering Geology, Vol.6, pp. 96, 1972.

12) Saunders, M.S. and Fookes, P.G. : A review of the relationship of rock weathering and climate and its sig. nificance to foundation engineering, Engineering Geology 4, pp. 289 325, 1970.

13) Ruxton, B. P. and Berry, L. : Weathering profiles and geomorphic position on granite in two tropical regions, Rev. Geomorph. Dynamique, 12, pp. 16 31, 1961.

14） Carroll, D. 著 (松尾新一郎 監訳)：岩石の風化, ラティ ス刊, pp. 158, 1974 年.

15) Olugboye, M. O. : Note on the hydrogeology of Kaduna River Basin around Kaduna Town, Kaduna State Geological Survey Report, No. 1539, Dec. 1975.

16）赤井浩一：土の粒度配合による締め固め特性の変化, 土 と基礎, Vol. 5, No. 5, pp. 19〜22, 1957 年.

17) Lumb, P. : The properties of decomposed granite, Geotechnique Vol. 12, No. 3, pp. 226 243, 1962.
18）土質基礎工学ライブラリー：風化花崗岩とまさ土の工学 的性質とその応用，土質工学会編，pp. 11，1979 年.

19) Lambe, T.W. and Whiteman, R. V. : Soil Mechanics, pp. 33, John Wiley \& Sons, Inc. 1969.

20）金子・末岡・安：脱鉄処理による土の物理化学的性質の 変化, 第 18 回土質工学発表会, pp. 171 174, 1983 年 6 月.

21）西田・青山：花コウ岩風化層の間ゲキ径分布と水分吸着 特性について, 応用地質, 20 巻 1 号, pp. 3 12, 1979 年.

22) Onodera, T., Oda, M. and Minami, K. : Shear strength of undisturbed sample of decomposed granite soil, Soil and Foundation, Vol.16, No.1, pp. 17 26, 1976.

23）三浦 清：島根県加茂町付近の花崗岩類とその崩壊につ いて, 岩鉱学会誌, 56 巻 6 号, pp. 256 283, 1966 年.

24) Lumb, P. : Safety factors and probability distribution of soil strength, Canadian Geotechnical Journal, Vol. 7, pp. 225 242, 1970.

25）松尾・黒田：不飽和土の土質諸係数と破壊確率に関する 一考察, 土木学会論文報告集, 第 208 号, pp. $65 \sim 75$, 1972 年 12 月.

26) Ruxton, B. P. and Berry, L. : Weathering of granite and associated erosional features in Hong Kong, Bull. Geol. Soc. America, Vol.68, pp. 1263 1291, 1957.

27) Little, A.L. : The engineering classification of residual tropical soils, Proc. Intern. Conf. on S. M. F. E. Mexico, 1, pp. 1 10, 1969.

28) Scott, L.E. : Secondary minerals in rock as a cause for base failure, Proc. Highway Res. Board. (Wash.) 34, pp. 412 417, 1955.

29) Reiche, P. : Graphic representation of chemical weathering, Jour. Sed. Petrology, Vol.13, pp. 58 68, 1943.

30) Ruxton, B. P. : Measures of the degree of chemical weathering of rocks, Jour. Geol. Vol.76, pp.518 $527,1968$.

31）三浦 清：深成岩の風化に関する研究 (第 1 報)一新第三 紀末の赤色風化作用による江津梁成岩体の風化, 応用地 質, Vol. 14, No. 3, pp. 1 16, 1973 年.

32）木宮一邦：花こう岩類の物理風化指標としての引張強度, 地質学雑誌, 第 81 巻第 6 号, pp. 349 364, 1975 年.

(1983.8.29 - 受付) 